\title{
Surface replacement arthroplasty of the proximal interphalangeal and metacarpophalangeal joints: The current state
}

\author{
Harvinder Singh, Joseph J. Dias \\ Department of Health Sciences, University of Leicester, Leicester, England, UK
}

Address for correspondence: Prof. J. J. Dias, Professor and Head of Hand and Orthopaedic Surgery, Department of Health Sciences, University of Leicester, Leicester, England, UK. E-mail: jd96@leicester.ac.uk

\begin{abstract}
Surface replacement arthroplasty for proximal interphalangeal joint and metacarpophalangeal joints are becoming popular. Low profile, anatomically designed implants limit the amount of bone removed but need preservation of the collateral ligaments. Pyrocarbon and cobalt-chrome stemmed unconstrained implants on ultra-high molecular weight polyethylene are the two commonly available bearing surfaces. The indications for small joint arthroplasty are degenerative, post-traumatic or rheumatoid arthritis. Early results are encouraging, primarily in patient satisfaction and pain relief, but are based on low numbers. The main concerns are progressive loss of range due to implant settling, dislocation, squeaking and poor osteo-integration with the appearance of a radiolucent line at the bone-implant interface. Our experience suggests that metacarpophalangeal joint replacements consistently give good results.
\end{abstract}

\section{KEY WORDS}

Finger; joint replacement; pyrocarbon

\section{EVOLUTION OF TECHNOLOGY}

dvances in small joint prostheses have followed developments in technology and materials since the Second World War. Vitallium was first used as a cap arthroplasty of metacarpophalangeal (MCP) and proximal interphalangeal (PIP) joints of fingers as it is inert and non-reactive. ${ }^{[1]}$ It increased motion in joints but provided little stability. Brannon and Klein in 1959 used

\begin{tabular}{|l|l|}
\hline \multicolumn{2}{|c|}{ Access this article online } \\
\hline Quick Response Code: & Website: \\
\hline & www.ijps.org \\
\cline { 2 - 2 } & \\
\hline
\end{tabular}

rigid hinge joints of stainless steel, and later titanium in young military patients with irreparably damaged finger joints. The triangular intramedullary stems designed to prevent rotation were the weak points resulting in bone resorption and loosening.

The attempts to overcome the problems of stem loosening led Flatt ${ }^{[2]}$ to develop a two-pronged stem to fit the medullary canal and prevent rotation in rheumatoid patients. These had a non-anatomic center of rotation, a high coefficient of friction at the hinge mechanism ultimately causing implant failure. Swanson rejected the need for stem fixation and hypothesized that the biologically inert and soft material was less likely to stimulate the absorption phenomenon seen with metal implants. ${ }^{[3]}$ This interposition arthroplasty had greater success as it provided a degree of stability with intrinsic 
flexibility. This implant acts through a piston movement rather than hinge action as the conical piston glides in and out of the fluid filled cavity. ${ }^{[4]}$

The success of the Charnley cemented hip joint replacement with the use of polyethylene led to the development of similar implants in hand joints. Linscheid and Dobyns ${ }^{[5]}$ developed an unconstrained total joint replacement for the PIP joint that relied on preservation of the collateral ligaments. A similar surface replacement arthroplasty has subsequently been developed for the MCP joint with anatomic, minimally constrained designs with smaller intramedullary stems that require preservation of the ligaments. The newer designs use biologically inert biomaterials, such as pyrocarbon, and uncemented osteointegrative methods.

The initial PIPJ surface arthroplasty used cobaltchrome stemmed unconstrained implants fixed with polymethylmethacrylate cement with a bearing of ultrahigh-molecular weight polyethylene (UHMWPE). But newer implants have uncemented hydroxyapatite-coated cobalt-chrome bearing on UHMWPE or of pyrocarbon and other composite materials. Pyrocarbon was first used in mechanical heart valves and is inert and compatible with normal bone. It has a synthetic high strength graphite core coated with a $0.42 \mathrm{~mm}$ thick pyrolytic carbon layer formed by heating a hydrocarbon gas to approximately $1300^{\circ} \mathrm{C}$. Pyrolytic carbon is a strong, durable and wearresistant material with elastic modulus similar to that of cortical bone, which makes it ideal for implant-bone stress transfer with a low rate of fracture. ${ }^{[6]}$ It has proved to be an excellent biomaterial for finger joints with excellent bone-implant incorporation, excellent wear properties with no evidence of an inflammatory reaction, wear debris or particulate synovitis in the long term. ${ }^{[7]}$

The anatomy, indication, technique, aftercare and outcomes of the PIP and MCP joint replacement are discussed in the following sections.

\section{PROXIMAL INTERPHALANGEAL JOINT SURFACE REPLACEMENT}

\section{Surgical anatomy}

The proximal interphalangeal (PIP) joint is an important link in the kinetic chain of the finger providing about $40 \%$ of the total active range of movement. ${ }^{[8]}$ It is particularly important for grasping smaller objects and handling irregularly shaped objects. It is a bicondylar joint with the head of proximal phalanx divided by the intercondylar concavity. It articulates with base of middle phalanx that presents two concavities separated by a saddle-shaped median ridge. This ridge forms a tubercle on the dorsum where the central slip of the extensor mechanism is attached. There are pits on the medial and the lateral aspects of the head of the proximal phalanx where the strong collateral ligaments are attached. The palmar plate takes its origin proximally from the checkrein ligaments attached to the neck of the proximal phalanx and inserts on a flat area on the palmar margin of middle phalanx. This palmar plate is unlike that of the metacarpophalangeal joint, which is not anchored to the metacarpal neck. The accessory collateral ligaments originate from pits close the main collateral ligaments but insert into the palmar plate. This soft tissue envelope, with extensor tendons, provides stability to the prosthetic joint.

The fixed centre of rotation is at the proximal insertion of the collateral ligaments and there is little change in tension of the collateral ligaments at different joint positions. The average range of movement is $90^{\circ}$. The PIP joint behaves like a hinge joint with $1^{\circ}$ of freedom only in flexion and extension but movement is also seen on lateral stress with $5^{\circ}$ of adduction and $9^{\circ}$ of supination. ${ }^{[9]}$ The functional range of motion of the PIP joint has been described as between $0^{\circ}$ and $-35^{\circ}$ of extension and $85^{\circ}$ of flexion. ${ }^{[10]}$ External pinch forces of $70 \mathrm{~N}$ are considered normal across the index and middle fingers and the PIP joint could be exposed to resultant forces as high as 6 times the applied force. ${ }^{[11]}$ It is important to preserve the collateral ligaments to allow the prosthetic joint to withstand pinch stresses. ${ }^{[12]}$

The indications for small joint arthroplasty are the same as those for large joints, namely degenerative, post-traumatic or rheumatoid arthritis. The relative contraindications to arthroplasty are young active patients, manual workers, and patients with significant bone loss, gross instability or previous infection.

\section{Pre-operative evaluation}

Careful evaluation of the joint allows measurement of the degree of deformity and restriction of motion. A carefully positioned AP and true lateral radiograph of the involved finger allows accurate assessment of the component sizes that best fill the medullary canal of the proximal and middle phalanx. Final selection of the prostheses 
will depend on the sizing at the time of surgery. The surgeon should discuss the post-operative finger PIP therapy regimen that could last many weeks. All potential complications should be discussed with the patient. If the arthroplasty fails, arthrodesis, interposition, fibrous arthroplasty or disarticulation may be necessary for finger salvage. Surface Arthroplasty is not suitable when there is significant bony deformity, extensive synovitis, more than $20^{\circ}$ of ulnar deviation on pre-operative radiographs, or if ligaments are incompetent.

\section{Surgical technique}

The replacement can be performed under local anaesthesia with a finger tourniquet but an arm tourniquet with regional or general anaesthesia is preferred. The joint can be approached in one of three directions, dorsally by lifting a distally based extensor tendon flap (Chamay approach $^{[13]}$ ) or as a longitudinal spilt of the central slip and this requires good repair to allow early rehabilitation. The palmar approach avoids injury to the extensor tendon and allows for a simpler approach to post-operative therapy. ${ }^{[14]} \mathrm{A}$ lateral ulnar-sided approach for the prosthetic replacement has been described and it requires detachment and subsequent reattachment of collateral ligament with a non-absorbable suture through drill holes. ${ }^{[15]}$

We prefer to approach the proximal interphalangeal joint through a longitudinal split of the extensor tendon [Figure 1]. This split is taken up to the attachment of the central slip, which is then detached from the base of the middle phalanx and soft tissue reflected, by sharp dissection, as a sleeve up to the anterior third attachment of the collateral ligament. This allows dislocation of the

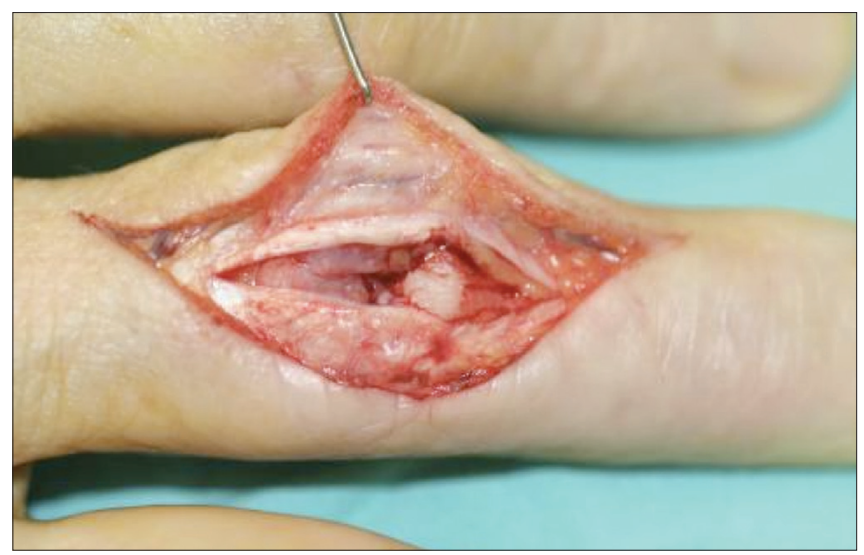

Figure 1: A curved incision is made on the dorsum of the proximal interphalangeal joint. The tendon is split. The central slip is reflected along with the periosteum of the middle phalanx to the mid lateral lines joint. A careful anterior stretching is done to mobilise the palmar plate away from the neck of the proximal phalanx. Any osteophytes along the sides of the condyle are excised using a fine rongeur.

The surface of the middle phalanx is then cut using an oscillating saw at right angles to the shaft of the middle phalanx. This forms the surface of reference. The finger is then extended and distracted. The extension gap is measured and a transverse cut is made using the oscillating saw across the distal part of the proximal phalanx. The extension gap should be sufficient to accommodate the thickness of both components of the implant. An anterior chamfer is then cut either using jigs or free hand depending on the implant used. Care is taken to ensure that any osteophytes in the front are carefully trimmed back. A full washout is then conducted.

The medullary canal of the middle phalanx is then opened and carefully broached to take the appropriate sized implant. The correct size is one that allows the plateau of the middle phalanx to be covered almost completely by the implant. The medullary canal of the proximal phalanx is then opened with the awl just behind the midline dividing the anterior half and the posterior half of the distal surface. The proximal phalanx is then broached. The aim is to fill the medullary canal with the largest implant stem possible. It is important that the stem is centralised within the shaft of the bones. This will avoid positioning the distal component too palmar. The trial implant is then introduced. The finger should extend and flex passively without the implant sticking or jacking open. This maltracking would indicate that the implant is put in too tight or either the extension gap or flexion gap is inadequate. Full washout of the debris is then repeated.

The decision is made at this stage whether or not to reattach the central slip with a bone suture. If this is considered then two fine $1 \mathrm{~mm}$ drill holes are made in the dorsum of base of the middle phalanx. A non-absorbable suture is passed through these holes. After a full washout, the middle phalangeal component is introduced first and impacted into place. Holding the joint flexed the proximal phalangeal component is then introduced and impacted with the correct impactors. A full washout is again done and the stability of the implant in extension and flexion assessed. If the stability has been compromised the collateral ligaments are carefully reattached with bone sutures. This is rarely required if care is taken. 
The central slip may be reattached to the through bone sutures in the base of the middle phalanx. [Figure 2] Alternatively just a continuous Proline suture is used to close the split in the extensor tendon without reattachment of the central slip to bone. If there is sufficient capsule, then this is closed prior to the closure of the tendon. Once the tendon is repaired the finger is passively extended and flexed to ensure that the repair is strong enough to allow early mobilisation. We usually use nylon sutures to close the skin.

We then apply a bulky padded dressing but do not use a plaster slab. The proximal interphalangeal joints and the metacarpophalangeal joints are held slightly flexed. The post-operative care is meticulous. Initially the hand is elevated for at least $2-3 \mathrm{~h}$. The patient is then allowed to actively flex the finger when in the bandage. This allows early recovery of active flexion. The fingers relax into their natural position in the bandage after each flexion [Figures 3 and 4].

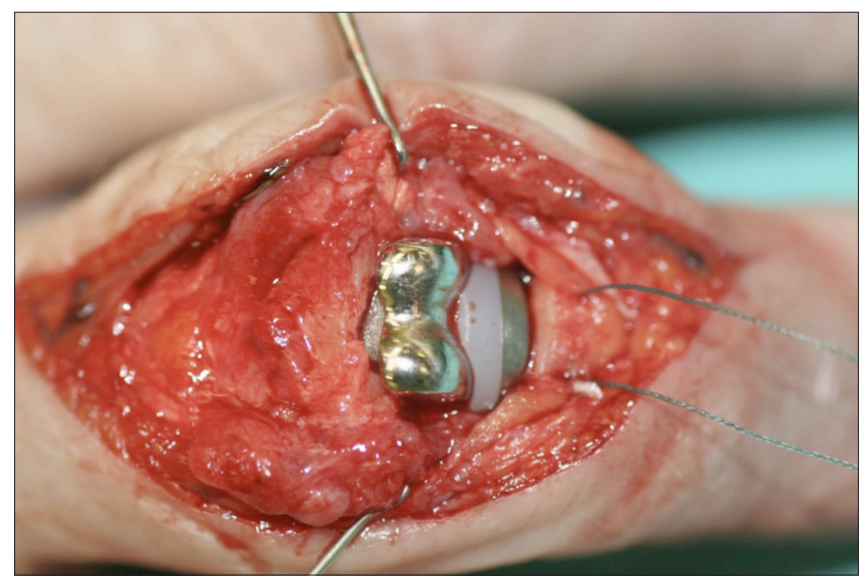

Figure 2: The proximal interphalangeal joint implant impacted into place. The two bone sutures introduced prior to the introduction of the implant into the base of the middle phalanx are seen. These are used to reattach central slip before longitudinal closure

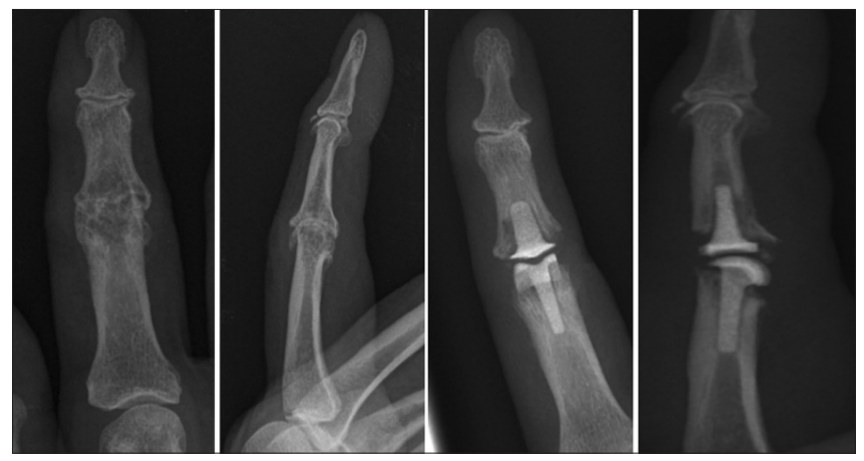

Figure 4: Pre-operative and post-operative radiographs of proximal interphalangeal joint replacement
The physiotherapist is allowed to reduce the bandages after a few days, use Coban bandaging to decrease swelling and institute a Norwich regime ${ }^{[16]}$ of exercises to protect the extensor mechanism, but allow early mobilisation. We do not routinely use splints in the postoperative period and find that these are rarely needed.

\section{Complications}

Careful soft-tissue balance, anatomical implant alignment and meticulous repair of tendon will avoid early dislocation, and the development of a swan neck or boutonnière deformity [Figure 5]. Infections, prosthesis cut out, settling, fracture and laxity can be difficult to manage, requiring fusion, excision and secondary reconstruction with a Silastic implant, or a palmar plate arthroplasty. Pyrocarbon implants are associated with squeaking ${ }^{[17]}$ and patients should be warned about it before surgery. The possible reasons for revision are improper case selection, poor surgical technique, inadequate prosthesis material and design. All patients with prosthetic finger joint replacement should be kept under regular clinical and radiological review to identify features of implant loosening and subsidence or tilting of

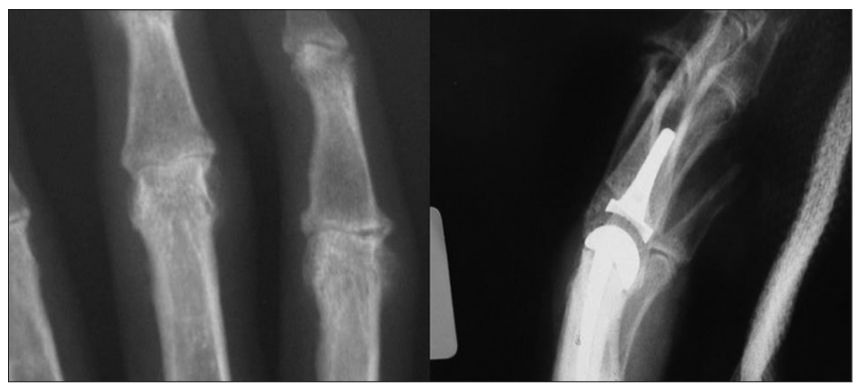

Figure 3: The pre-operative and post-surgical radiographs of the proximal interphalangeal joint surface replacement showing the implant in place. The joint is congruent. The stems of each implant are centrally located within the respective bone

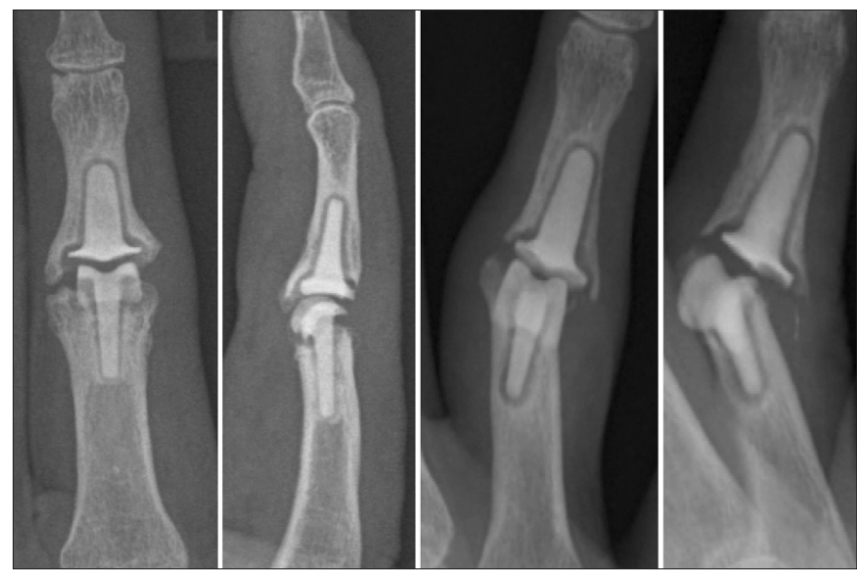

Figure 5: Radiographs showing subsidence of the implant and swan neck deformity 
the implant and to detect early catastrophic failures such as the LPM (Leuwen, Poeschmann, Metal) prosthesis (Van Straten Medical, Nieuwegein, Holland). ${ }^{\mid 18]}$

\section{Outcomes}

The main concern for all the PIP surface implants is the progressive loss of range due to implant settling [Figure 5]. Tables 1 and 2 summarizes the literature on the PIPJ surface replacement..17,19-31] The pyrocarbon implant often shows a radiolucent line around the implant at the bone-implant interface suggesting poor osseo-integration. ${ }^{[20]}$ But this radiolucency is usually not progressive and does not result in implant failure. The reported outcomes are worse in digits with pre-existing deformity or extreme bone and/or soft tissue loss

\section{METACARPOPHALANGEAL JOINT SURFACE REPLACEMENT}

\section{Surgical anatomy}

The MCPJ is a condylar ball-and-socket joint with a convex surface on the metacarpal head and an incongruent (larger radius of curvature) concave surface on the proximal phalanx. On either side of the joint lie the collateral ligaments, running from the metacarpal tubercles to the palmar two-thirds of the lateral margin of the phalangeal base and the lateral margin of the palmar plate. The ligaments are eccentrically oriented such that ligament length changes depending on the relationship to the fixed joint axis, an intrinsic property known best as the 'cam' effect. ${ }^{[32]}$ The muscle and tendon forces are the primary joint stabilizers acting to sustain pinch and grasp, while the joint ligaments and capsule provide initial stability to instantaneous forces and provide second-line defense in maintaining stability during static peak loading conditions. The thick palmar plate of the flexor tendon sheath has negligible attachment to the fibers of the joint capsule or to the metacarpal. The palmar plate is able to move with the proximal phalanx independent of the metacarpal. This joint allows $150^{\circ}$ of flexion/extension and up to $57^{\circ}$ of radio-ulnar deviation in extension, although most activities of daily living are achieved in an arc of $10^{\circ}-70^{\circ}$ of flexion. The collateral ligament length is $14 \mathrm{~mm}$ with $20^{\circ}$ of MCP extension, 17 $\mathrm{mm}$ with $0^{\circ}$ of flexion, $19 \mathrm{~mm}$ with $50^{\circ}$ of flexion, and $18 \mathrm{~mm}$ with $90^{\circ}$ of flexion. These observations provide the justification for splinting the MCP in $50^{\circ}$ of flexion to prevent an extension contracture. ${ }^{[33]}$ In addition, the skin and soft tissue around the MCP joint, the transverse intermetacarpal ligament, and the flexor retinaculum through the sagittal bands all play a stabilizing role. To clinically test the integrity of the MCP collateral ligaments, the joint should be placed into $90^{\circ}$ of flexion with force applied in a radial and ulnar direction, testing for laxity compared to the corresponding contralateral digit. The MCPJ is subjected to significant forces, up to $190 \mathrm{~N}$ during a pinch manoeuvre and probably more in power grip..$^{[34]}$

The prosthetic MCPJ replacement is most commonly indicated for rheumatoid arthritis and Silastic interpositional replacement with soft tissue rebalancing

Table 1: Prosthetic types, status of ligaments, bearing surfaces and examples of PIPJ and MCPJ replacement

\begin{tabular}{|c|c|c|c|c|}
\hline Prosthesis type & Extent of excision & Ligaments & Bearing & Examples \\
\hline $\begin{array}{l}\text { Interpositional } \\
\text { arthroplasty }\end{array}$ & $\begin{array}{l}\text { Non-anatomic excision/ } \\
\text { Intramedullary stability }\end{array}$ & $\begin{array}{l}\text { Excised/ already } \\
\text { detached or } \\
\text { dysfunctional }\end{array}$ & Silastic & $\begin{array}{l}\text { Swanson silicone, neuflex, } \\
\text { sutter }\end{array}$ \\
\hline $\begin{array}{l}\text { Surface replacement } \\
\text { arthroplasty }\end{array}$ & Anatomical excision & Preserved or repaired & $\begin{array}{l}\text { Pyrocarbon } \\
\text { proximal cobalt } \\
\text { chromium, distal } \\
\text { component cemented } \\
\text { UHMHPE/ press-fit } \\
\text { cementless textured } \\
\text { titanium. }\end{array}$ & $\begin{array}{l}\text { Pyrocarbon, } \\
\text { PIP-SRA }\end{array}$ \\
\hline $\begin{array}{l}\text { Semi constrained/ } \\
\text { constrained (linked } \\
\text { arthroplasty) }\end{array}$ & $\begin{array}{l}\text { Intramedullary fixation } \\
\text { rather thananatomic } \\
\text { configuration, conisation } \\
\text { of the bone }\end{array}$ & $\begin{array}{l}\text { Unstable joints with } \\
\text { dysfunctional collateral } \\
\text { ligaments }\end{array}$ & $\begin{array}{l}\text { Stainless steel, Cobalt } \\
\text { chromium, cemented } \\
\text { UHMHPE/ press-fit } \\
\text { cementless textured } \\
\text { titanium.Stabilizing } \\
\text { midline crest between } \\
\text { theproximal and distal } \\
\text { components }\end{array}$ & $\begin{array}{l}\text { Keesler, hagert, sibly- } \\
\text { unsworth, Digitos, } \\
\text { saffar, DJOA3, } \\
\text { weckoFingergrundgelenk } \\
\text { prosthesis }\end{array}$ \\
\hline
\end{tabular}


has $63 \%$ survival at 17 years. ${ }^{[35]}$ In patients with primary or post-traumatic osteoarthritis, early failure may occur with the Silastic implant as a result of the high stresses going through the joint. ${ }^{[35]}$ In these cases, anatomical surface replacement arthroplasty is a better option.

\section{Pre-operative assessment}

The surface arthroplasty is used in patients with osteoand post-traumatic arthritis with normal soft tissue envelopes with competent ligaments. In patients with rheumatoid arthritis, soft tissue imbalance may be more severe, and the surgeon must determine that correction of palmar subluxation deformities and ulnar deviation can be achieved and the joint will be stable after surface replacement, with competent ligaments. The risk of failure of the procedure should be discussed with the patient and salvage may require conversion to a Silastic implant.

\section{Surgical technique}

For a single- or two-digit arthroplasty, longitudinal incisions are used to expose the extensor mechanism. We prefer to split the extensor tendon. A slightly curved incision is made over the dorsum of the metacarpophalangeal joint, extending from the middle of the proximal phalanx to the distal third of the metacarpal.

Table 2: Outcome after surface replacement arthroplasty proximal interphalangeal joint (metal and pyrocarbon)

\begin{tabular}{|c|c|c|c|c|c|c|c|}
\hline Study & Total joints & $\begin{array}{l}\text { Improved arc } \\
\text { of motion } \\
\text { (degrees) }\end{array}$ & $\begin{array}{l}\text { Method of } \\
\text { treatment }\end{array}$ & Results & $\begin{array}{l}\text { Follow-up } \\
\text { (years) }\end{array}$ & Complication & Comments \\
\hline $\begin{array}{l}\text { Linscheid et al., } \\
1997\end{array}$ & 65 & $35-47$ & $\begin{array}{l}\text { Cemented cobalt } \\
\text { chrome and } \\
\text { UHMHPE }\end{array}$ & $\begin{array}{l}\text { Pain relief } \\
\text { in } 56 \text { of } 65 \\
\text { joints }\end{array}$ & 4.5 & 19 & $\begin{array}{l}\text { Instability ( } 5 \text { joints), } \\
\text { coronial deviation } \\
\text { ( } 4 \text { joints), extensor } \\
\text { lag }>50^{\circ} \text { ( } 2 \text { joints), } \\
\text { swan neck deformity } \\
\text { ( } 5 \text { joints), Repeat } \\
\text { surgery ( } 12 \text { joints) }\end{array}$ \\
\hline $\begin{array}{l}\text { Johnstone, } \\
2008\end{array}$ & $\begin{array}{c}24 \text { (cemented), } \\
19 \\
\text { (uncemented) }\end{array}$ & $43-52$ & $\begin{array}{l}\text { Proximal cobalt- } \\
\text { chromium (both), } \\
\text { distal component } \\
\text { cemented } \\
\text { UHMHPE/ press- } \\
\text { fit cementless } \\
\text { textured titanium }\end{array}$ & $\begin{array}{l}\text { VAS score } \\
\text { from } 6.5 \text { to } 1\end{array}$ & 5.5 & 28 & $\begin{array}{l}\text { Lower loosening } \\
\text { rates and subsidence } \\
\text { with cemented } \\
\text { than uncemented } \\
\text { prosthesis. } \\
(P=0.0003)\end{array}$ \\
\hline $\begin{array}{l}\text { Jennings and } \\
\text { Livingstone, } \\
2008\end{array}$ & 43 & $36-58$ & $\begin{array}{l}\text { Proximal cobalt- } \\
\text { chromium, distal } \\
\text { UHMHPE on } \\
\text { cementless } \\
\text { textured titanium }\end{array}$ & $\begin{array}{l}38 \text { of } 43 \\
\text { satisfactory }\end{array}$ & 3 & 18 & $\begin{array}{l}2 \text { of } 45 \text { cemented } \\
\text { prosthesis loose, } 16 \\
\text { of } 41 \text { uncemented } \\
\text { prosthesis loose. } \\
11 \text { joints needed } \\
\text { resurgery (fusion) }\end{array}$ \\
\hline $\begin{array}{l}\text { Tuttle and Stern, } \\
2006\end{array}$ & 18 & No mean change & $\begin{array}{l}\text { Pyrolytic carbon } \\
\text { implants }\end{array}$ & $\begin{array}{l}\text { VAS score } \\
\text { from } 8 \text { to } 3.5\end{array}$ & 1.1 & 7 & $\begin{array}{l}8 \text { squeaky joints, } 5 \\
\text { joint contractures, } 8 \\
\text { continued to cause } \\
\text { pain, } 2 \text { Dislocations } \\
\text { (closed reduction) }\end{array}$ \\
\hline Nunley, 2006 & 7 & -10 & $\begin{array}{l}\text { Pyrolytic carbon } \\
\text { implants }\end{array}$ & No relief & 1.5 & 5 & $\begin{array}{l}\text { One amputation, } \\
\text { one converted to } \\
\text { Silastic joint. Authors } \\
\text { recommended } \\
\text { against use of this } \\
\text { prosthesis for post- } \\
\text { traumatic arthritis }\end{array}$ \\
\hline Herren, 2006 & 17 & $34-42$ & $\begin{array}{l}\text { Pyrolytic carbon } \\
\text { implants }\end{array}$ & $\begin{array}{l}\text { Pain score } \\
7.6 \text { to } 1.3\end{array}$ & 1.8 & 4 & $\begin{array}{l}\text { Migration } 8 \text { implants, } \\
\text { increased radiolucent } \\
\text { lines } 3 \text { implants }\end{array}$ \\
\hline Meier, 2007 & 24 & Postop flexion 50 & $\begin{array}{l}\text { Pyrolytic carbon } \\
\text { implants }\end{array}$ & $\begin{array}{l}\text { Postop VAS } \\
\text { score }(0-3)\end{array}$ & 1.3 & 3 & $\begin{array}{l}\text { One infection, } \\
2 \text { dislocations } \\
\text { (arthrodesis), } 9 \\
\text { squeaking }\end{array}$ \\
\hline
\end{tabular}

Table 2 (contd...) 
Table 2 (contd...)

Table 2: Outcome after surface replacement arthroplasty proximal interphalangeal joint (metal and pyrocarbon)

\begin{tabular}{|c|c|c|c|c|c|c|c|}
\hline Study & Total joints & $\begin{array}{c}\text { Improved arc } \\
\text { of motion } \\
\text { (degrees) }\end{array}$ & $\begin{array}{l}\text { Method of } \\
\text { treatment }\end{array}$ & Results & $\begin{array}{l}\text { Follow-up } \\
\text { (years) }\end{array}$ & Complication & Comments \\
\hline $\begin{array}{l}\text { Branam and } \\
\text { Stern, } 2007\end{array}$ & 19 & $63-66$ & $\begin{array}{l}\text { Pyrolytic carbon } \\
\text { implants }\end{array}$ & $\begin{array}{l}\text { VAS } \\
\text { improved } \\
1.8\end{array}$ & 1.7 & 6 & $\begin{array}{l}8 \text { of } 19 \text { joints } \\
\text { squeaked, } 2 \text { early } \\
\text { dislocations and } 2 \\
\text { implants radiographic } \\
\text { loosening }\end{array}$ \\
\hline Bravo, 2007 & 50 & No mean change & $\begin{array}{l}\text { Pyrolytic carbon } \\
\text { implants }\end{array}$ & $\begin{array}{l}\text { VAS score } \\
\text { from } 6 \text { to } 0\end{array}$ & 2 & 14 & $\begin{array}{l}20 \text { showed } \\
\text { radiographic } \\
\text { subsidence, } 14 \text { joints } \\
\text { required additional } \\
\text { surgery }\end{array}$ \\
\hline $\begin{array}{l}\text { Chung and Ram, } \\
2009\end{array}$ & 21 & $38-40$ & $\begin{array}{l}\text { Pyrolytic carbon } \\
\text { implants }\end{array}$ & $\begin{array}{l}\text { MHQ Pain } \\
\text { effect size } \\
2.2\end{array}$ & 1 & 3 & $\begin{array}{l}3 \text { patients had } \\
\text { squeaking, } 3 \\
\text { dislocations }\end{array}$ \\
\hline Luther, 2009 & 24 & $33-54$ & $\begin{array}{l}\text { Pyrolytic carbon } \\
\text { implants }\end{array}$ & $\begin{array}{l}\text { Postop VAS } \\
\text { score (0- 7) }\end{array}$ & 1.9 & 14 & $\begin{array}{l}14 \text { reoperations: } \\
9 \text { teno-arthrolysis, } \\
\text { Proximal } \\
\text { interphalangeal (PIP) } \\
\text { tenodesis (one in } \\
\text { three with swan neck } \\
\text { deformity), ( } 4 \text { with } \\
\text { infections/loosening) }\end{array}$ \\
\hline Wijk, 2010 & 53 & $56-52$ & $\begin{array}{l}\text { Pyrolytic carbon } \\
\text { implants }\end{array}$ & $\begin{array}{l}\text { VAS score } \\
\text { from } 6.2 \text { to } 2\end{array}$ & 2 & 7 & $\begin{array}{l}7 \text { required re- } \\
\text { operation. } 2 \\
\text { arthrodesis, } 2 \\
\text { tenolysis, } 1 \text { post- } \\
\text { operative infection } \\
\text { with skin necrosis }\end{array}$ \\
\hline
\end{tabular}

There are two more articles available in literature on PIPJ replacement in German language. ${ }^{[38,39]}$

The extensor tendon is split longitudinally and reflected to either side. The capsule is then incised longitudinally. The distal attachment of the capsule is released in continuity with the periosteum right up to the anterolateral corner of the base of the proximal phalanx. Care is taken to preserve the attachments of the collateral ligament. An assessment is then made of the articular cartilage and marginal osteophytes are defined and excised using a fine rongeur. Both the proximal and distal attachment of the collateral ligaments are identified and protected, particularly the radial collateral ligaments.

Under distraction the base of the proximal phalanx is cut using an oscillating saw perpendicular to the long axis of the proximal phalanx. This cut forms the frame of reference for the remaining cuts [Figure 6]. The head of the metacarpal is then cut transversely and parallel to base of the proximal phalanx with the digit held extended and distracted. The extension gap accommodates the thickness of both components. If the implant equipment provides cutting jigs, these are used. Any anterior and posterior chamfers are then cut using appropriate jigs, if available. [Figure 7]

The distal bone is broached first. This is to ensure that the narrower bone determines the implant size. The centre of the canal is opened with an awl and the correct brooches are used until an appropriate implant is chosen. The correct implant is one whose plateau covers the margins of the base of the proximal phalanx [Figure 8].

The centre of the metacarpal is identified and the metacarpal is broached to the same size chosen by the preparation of the proximal phalanx. The trial implants are put in, the joint located and the range of movement assessed to ensure smooth gliding in full flexion and full extension with slight hyperextension. Laxity in flexion and extension is assessed.

The entire joint is then carefully washed out and any reaming debris carefully removed from each layer. The chosen implant is then introduced; the phalangeal 


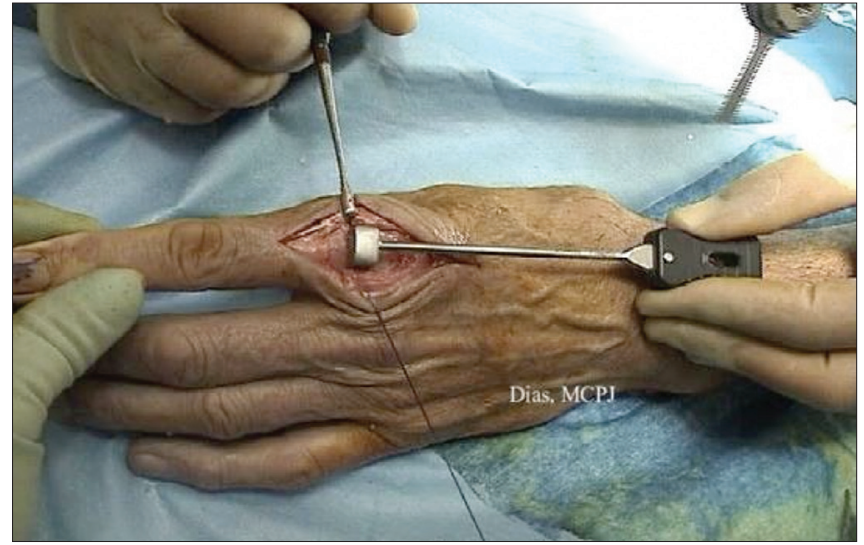

Figure 6: The cut made at the base of the proximal phalanx using the appropriate alignment jig

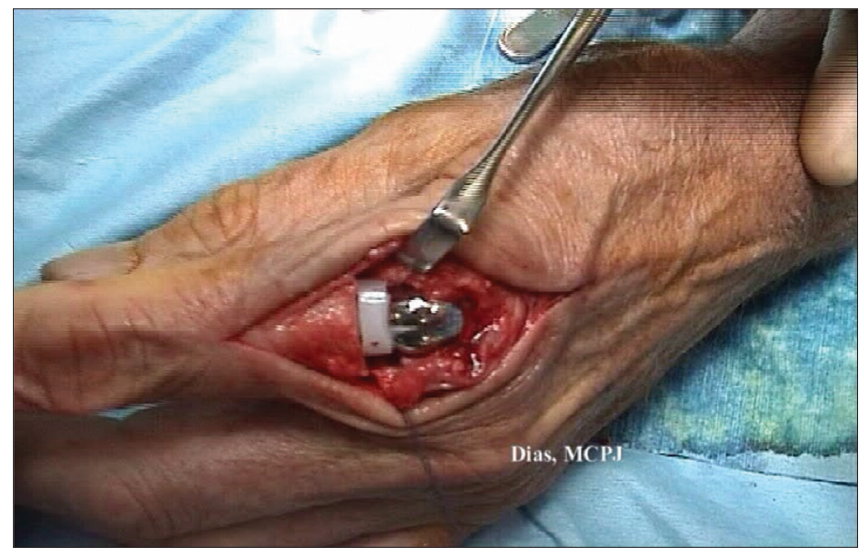

Figure 8: The metacarpophalangeal joint is in place. The joint is then flexed and extended and its stability checked

component is introduced first and impacted into place. The metacarpal component is then introduced and also impacted into place. The joint is relocated and again assessed. A final washout is done. Careful closure is conducted in layers with closure of the capsule followed by repair of the split tendon using a non-absorbable fine suture. The skin is then closed. A bulky wool and crepe bandage is applied holding the metacarpophalangeal joints slightly flexed. We do not use a plaster cast.

In the immediate post-operative period, the hand is held elevated for $2-3 \mathrm{~h}$. The patient is usually discharged home the same day. Active range-of-movement exercises are started when the hand is still in the bandage. Once the wound has healed full range-of-movement exercises are started. Again, once the wound has healed and full range has been restored the patient is allowed to resume all activity.

\section{Outcomes}

Metacarpophalangeal replacements in our experience are

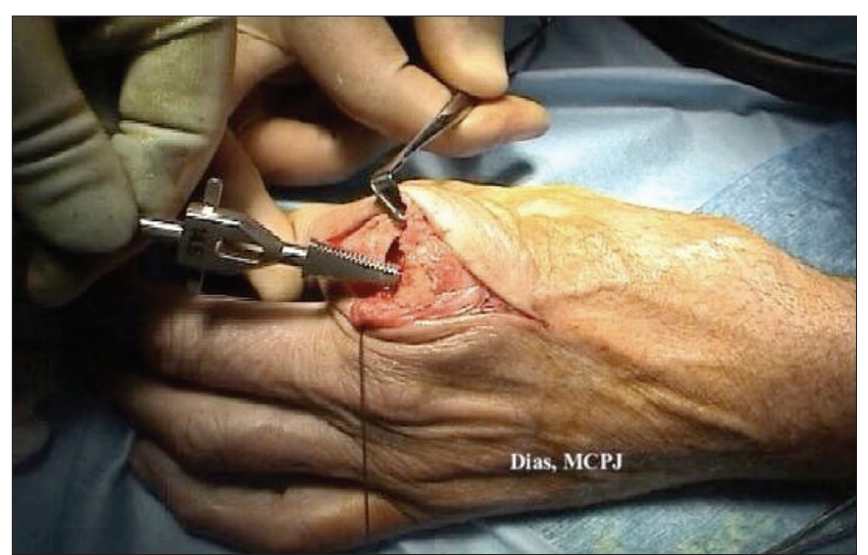

Figure 7: Brooches are used to shape the medullary canal to fit the shape of the stem of the implant

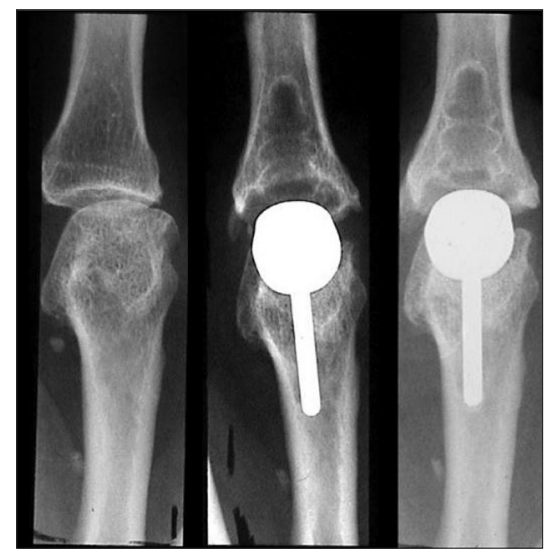

Figure 9: The pre-operative appearance of the arthritic metacarpophalangeal (MCP) joint. A metal and plastic implant has been introduced. The second picture is the radiograph obtained at 24 months. The third picture is of the same joint at 46 months No subsidence seen of either implant. No increasing lucency is seen around either implant. (The picture has been previously published in J Hand Surgery Br. 2003 Oct; 28(5): 432-8 by SAGE Publications Ltd.)

more successful [Figure 9]. The senior author presented his results at 5 years in 13 joints. It showed one revision for infection, and evidence of loosening of two phalangeal and one metacarpal component. Joint movement had improved from an arc of $27^{\circ}$ to $60^{\circ}$ and disability, assessed using the P.E.M. questionnaire, had improved from $77 \%$ to 9\%. ${ }^{36]}$ Silastic interpositional arthroplasty has become a gold standard for the MCPJ replacement in rheumatoid patients but metal or pyrolytic joint replacements have been used for osteoarthritic joints. Pyrocarbon unconstrained anatomical MCPJ replacements were used in 53 patients with predominantly rheumatoid arthritis in 151 joints with a 10 -year survival rate of $81.4 \% .{ }^{[7]}$ But in rheumatoid patients, implant subsidence and loosening can occur due to disease progression. ${ }^{[37]}$ The preliminary results of the pyrocarbon replacement in $10 \mathrm{MCP}$ joints with osteoarthritis at 2.2 years showed improvement in pain scores from $68 \%$ to $3 \%$ and a high patient satisfaction 
rate. ${ }^{[38]}$ Clinical and radiological results were reported using an anatomical MCPJ implant with cobalt chrome on an ultra-high UHMWPE bearing. The proximal cobaltchrome component is inserted into an UHMWPE press-fit sleeve that is itself inserted into the metacarpal with an interference fit.

\section{Complications}

Subluxation or dislocations of the unconstrained components, loosening or migration of implants, implant fracture and joint stiffness have been described. ${ }^{[39]}$ A loose implant may be revised to a larger prosthesis with bone grafting. If an implant is to be removed, then the surgeon may consider salvage revision to a Silastic implant or palmar plate arthroplasty.

\section{SUMMARY}

Joint stability, realignment and balance of soft tissues remain the primary challenges to surface replacement arthroplasty in the fingers. These limit bone resection and preserve the integrity of collateral ligaments, thus maintaining stability and reducing axial torque at the bone-cement interface. When marked bone loss is present or collateral ligaments have been rendered incompetent, more constrained designs may be more appropriate. Joint replacements are promising but we await medium-term outcomes.

\section{REFERENCES}

1. Burman M. Vitallium cup arthroplasty of metacarpophalangeal joint and interphalangeal joints of fingers. Bull Hosp Joint Dis 1940;1:79-89.

2. Flatt AE. Restoration of Rheumatoid Finger-Joint Function. J Bone Joint Surg Am 1963;45:1101-3.

3. Swanson $A B$. Finger joint replacement by silicone rubber implants and the concept of implant fixation by encapsulation. Ann Rheum Dis 1969;28-5:Suppl:47-55.

4. Hagert CG, Eiken O, Ohlsson NM, Aschan W, Movin A. Metacarpophalangeal joint implants. I. Roentgenographic study on the silastic finger joint implant, swanson design. Scand J Plast Reconstr Surg 1975;9-2:147-57.

5. Linscheid RL, Dobyns JH. Total joint arthroplasty. The hand. Mayo Clin Proc 1979;54-8:516-26.

6. Cook SD, Klawitter JJ, Weinstein AM. The influence of implant elastic modulus on the stress distribution around LTI carbon and aluminum oxide dental implants. J Biomed Mater Res 1981;156:879-87.

7. Cook SD, Beckenbaugh RD, Redondo J, Popich LS, Klawitter JJ, Linscheid RL. Long-term follow-up of pyrolytic carbon metacarpophalangeal implants. J Bone Joint Surg Am 1999;815:635-48.

8. Murray PM. Surface replacement arthroplasty of the proximal interphalangeal joint. J Hand Surg Am 2007;32-6:899-904.
9. Minamikawa Y, Horii E, Amadio PC, Cooney WP, Linscheid RL, An KN. Stability and constraint of the proximal interphalangeal joint. J Hand Surg Am 1993;18-2:198-204.

10. Herren DB, Simmen BR. Palmar approach in flexible implant arthroplasty of the proximal interphalangeal joint. Clin Orthop Relat Res 2000-371:131-5.

11. Beevers DJ, Seedhom BB. Metacarpophalangeal joint prostheses: a review of past and current designs. Proc Inst Mech Eng H 1993;207-4:195-206.

12. Ash HE, Unsworth A. Proximal interphalangeal joint dimensions for the design of a surface replacement prosthesis. Proc Inst Mech Eng H 1996;210-2:95-108.

13. Chamay A. A distally based dorsal and triangular tendinous flap for direct access to the proximal interphalangeal joint. Ann Chir Main 1988;7-2:179-83.

14. Duncan SF, Merritt MV, Kakinoki R. The volar approach to proximal interphalangeal joint arthroplasty. Tech Hand Up Extrem Surg 2009;13-1:47-53.

15. Segalman KA. Lateral approach to proximal interphalangeal joint implant arthroplasty. J Hand Surg Am 2007;32-6:905-8.

16. Sylaidis $P$, Youatt $M$, Logan $A$. Early active mobilization for extensor tendon injuries. The Norwich regime. J Hand Surg $\mathrm{Br}$ 1997;22-5:594-6.

17. Chung KC, Ram AN, Shauver MJ. Outcomes of pyrolytic carbon arthroplasty for the proximal interphalangeal joint. Plast Reconstr Surg 2009;123-5:1521-32.

18. Hobby JL, Edwards S, Field J, Giddins G. A report on the early failure of the LPM proximal interphalangeal joint replacement. $J$ Hand Surg Eur Vol 2008;33-4:526-7.

19. Linscheid RL, Murray PM, Vidal MA, Beckenbaugh RD. Development of a surface replacement arthroplasty for proximal interphalangeal joints. J Hand Surg Am 1997;22-2:286-98.

20. Johnstone BR, Fitzgerald M, Smith KR, Currie LJ. Cemented versus uncemented surface replacement arthroplasty of the proximal interphalangeal joint with a mean 5-year follow-up. $J$ Hand Surg Am 2008;33-5:726-32.

21. Jennings $C D$, Livingstone DP. Surface replacement arthroplasty of the proximal interphalangeal joint using the PIP-SRA implant: results, complications, and revisions. J Hand Surg Am 2008;339:1565 e1-11.

22. Tuttle HG, Stern PJ. Pyrolytic carbon proximal interphalangeal joint resurfacing arthroplasty. J Hand Surg Am 2006;31-6:930-9.

23. Nunley RM, Boyer MI, Goldfarb CA. Pyrolytic carbon arthroplasty for posttraumatic arthritis of the proximal interphalangeal joint. J Hand Surg Am 2006;31-9:1468-74.

24. Herren DB, Schindele S, Goldhahn J, Simmen BR. Problematic bone fixation with pyrocarbon implants in proximal interphalangeal joint replacement: short-term results. J Hand Surg $\mathrm{Br} 2006 ; 31$ 6:643-51.

25. Meier R, Schulz M, Krimmer H, Stutz N, Lanz U. Proximal interphalangeal joint replacement with pyrolytic carbon prostheses. Oper Orthop Traumatol 2007;19-1:1-15.

26. Branam BR, Tuttle HG, Stern PJ, Levin L. Resurfacing arthroplasty versus silicone arthroplasty for proximal interphalangeal joint osteoarthritis. J Hand Surg Am 2007;32-6:775-88.

27. Bravo CJ, Rizzo M, Hormel KB, Beckenbaugh RD. Pyrolytic carbon proximal interphalangeal joint arthroplasty: results with minimum two-year follow-up evaluation. J Hand Surg Am 2007;32-1:1-11.

28. Luther C, Germann G, Sauerbier M. Proximal Interphalangeal Joint Replacement with Surface Replacement Arthroplasty (SR-PIP): Functional Results and Complications. Hand (N Y) 2009;5:233-240.

29. Wijk U, Wollmark M, Kopylov P, Tagil M. Outcomes of proximal 
interphalangeal joint pyrocarbon implants. J Hand Surg Am;351:38-43.

30. Stutz N, Meier R, Krimmer H. [Pyrocarbon prosthesis for finger interphalangeal joint replacement. Experience after one year]. Unfallchirurg 2005;108-5:365-9.

31. Schulz M, Muller-Zimmermann A, Behrend $M$, Krimmer $H$. [Early results of proximal interphalangeal joint replacement with pyrolytic carbon prosthesis (Ascension) in idiopathic and posttraumatic arthritis]. Handchir Mikrochir Plast Chir 2005;37-1: 26-34.

32. Youm Y, Gillespie TE, Flatt AE, Sprague BL. Kinematic investigation of normal MCP joint. J Biomech 1978;11-3:109-18.

33. Glickel SZ, Millender LH. Ligamentous reconstruction for chronic intercarpal instability. J Hand Surg Am 1984;9-4:514-27.

34. Berme N, Paul JP, Purves WK. A biomechanical analysis of the metacarpophalangeal joint. J Biomech 1977;10-7:409-12.

35. Trail IA, Martin JA, Nuttall D, Stanley JK. Seventeen-year survivorship analysis of silastic metacarpophalangeal joint replacement. J Bone Joint Surg Br 2004;86-7:1002-6.
36. Harris D, Dias JJ. Five-year results of a new total replacement prosthesis for the finger metacarpo-phalangeal joints. J Hand Surg $\mathrm{Br}$ 2003;28-5:432-8.

37. Parker WL, Rizzo M, Moran SL, Hormel KB, Beckenbaugh RD. Preliminary results of nonconstrained pyrolytic carbon arthroplasty for metacarpophalangeal joint arthritis. J Hand Surg Am 2007;32-10:1496-505.

38. Nunez VA, Citron ND. Short-term results of the Ascension pyrolytic carbon metacarpophalangeal joint replacement arthroplasty for osteoarthritis. Chir Main 2005;24-3-4:161-4.

39. Syed MA, Smith A, Benjamin-Laing H. Pyrocarbon implant fracture after metacarpophalangeal joint arthroplasty: an unusual cause for early revision. J Hand Surg Eur Vol;35-6:505-6.

How to cite this article: Singh H, Dias JJ. Surface replacement arthroplasty of the proximal interphalangeal and metacarpophalangeal joints: The current state. Indian J Plast Surg 2011;44:317-26.

Source of Support: Nil, Conflict of Interest: None declared. 